\title{
Physical, Thermal, Mechanical Properties, and Microstructural Characterization of $\mathrm{Sn}-9 \mathrm{Zn}-\mathrm{XGa}$ Alloys
}

\author{
TOMASZ GANCARZ
}

The microstructural features, physicochemical, thermal, and mechanical properties of eutectic SnZn alloys with varying Ga contents were examined in this study. In the microstructure study using scanning electron microscope and X-ray diffraction analysis, intermetallic phases were not observed. The results indicated that the primary effect of $\mathrm{Ga}$ was increased mechanical properties. The physicochemical properties of liquid alloys, density, viscosity, and surface tension were measured using the free flow method. The addition of Ga to eutectic $\mathrm{SnZn}$ alloy generally reduced density, surface tension, viscosity, and melting point, and increased the coefficient of thermal expansion and electrical resistivity.

DOI: $10.1007 / \mathrm{s} 11661-015-3235-3$

(C) The Author(s) 2015. This article is published with open access at Springerlink.com

\section{INTRODUCTION}

REDUCING the melting temperature is one of the objectives in finding a replacement for lead-free solders. The melting temperature of eutectic $\mathrm{SnPb}$ is $456 \mathrm{~K}$ $\left(183{ }^{\circ} \mathrm{C}\right)$, which compares to alternatives as follows: SnZn $471 \mathrm{~K}\left(198^{\circ} \mathrm{C}\right)$, Sn-Cu-Ag $490 \mathrm{~K}\left(217^{\circ} \mathrm{C}\right)$, SnAg $494 \mathrm{~K}\left(221^{\circ} \mathrm{C}\right)$, and $\mathrm{Sn}-\mathrm{Cu} 500 \mathrm{~K}\left(227^{\circ} \mathrm{C}\right)$, as presented by Zhang and $\mathrm{Tu}^{\left[{ }^{[1]}\right.}$ As shown in the preliminary study performed by Reference 2, the melting point is reduced with the addition of Ga to SnZn alloys. In the same study, the authors showed an increase of the wetting rate and a reduction of wetting angle with increasing addition of Ga. Chen et al. ${ }^{[3]}$ obtained similar data for the wetting test on $\mathrm{Cu}$ substrate using $\mathrm{SnZn}$ alloys with $\mathrm{Ga}$, observing an increasing spreading area, but only to $0.5 \mathrm{Ga}$. For $1.0,2.0$, and $3.0 \mathrm{Ga}$ the spreading area values were the same. In the soldering process, the thickness of intermetallic phases (IMPs) at the interface of the solder and $\mathrm{Cu}$ substrate with the addition of Ga to alloys increased. Song et al. ${ }^{[4]}$ studied the microstructure, thermal, and tensile properties of SnZn-Ga alloys to $1.8 \mathrm{wt}$ pet Ga content. Reducing melting temperature and increasing tensile strength with increasing addition of $\mathrm{Ga}$ to eutectic $\mathrm{SnZn}$ were shown. ${ }^{[4]}$ Xue et al. ${ }^{[5]}$ investigated the influence of $\mathrm{Pr}$ addition to SnZn $(0.5 \mathrm{Ga})$, and the obtained IMPs layer thickness for an $\mathrm{SnZn}(0.5 \mathrm{Ga})$ alloy on $\mathrm{Cu}$ substrate was similar to that found by previous authors. ${ }^{[3]}$ The addition of $\mathrm{Ga}$, which dissolves in eutectic $\mathrm{SnZn}$ alloys as observed in Reference 4, caused increasing tensile strength, and similar effect was obtained for the addition

TOMASZ GANCARZ, Assistant Professor, is with the Polish Academy of Sciences, Institute of Metallurgy and Materials Science, Reymonta 25 St., 30-059 Kraków, Poland. Contact e-mails: tomasz. gancarz@imim.pl; t.gancarz@imim.pl

Manuscript submitted April 4, 2015

Article published online November 16, 2015 of $\mathrm{Na}$ to SnZn alloys. However, in the latter case, increasing tensile strength was indicated for precipitates of IMPs $\mathrm{Na}-\mathrm{Sn}$ and $\mathrm{Na}-\mathrm{Zn}$.

The aim of this study is to identify the characteristics of SnZn eutectic alloys with Ga additions $(0.1,0.2,0.5$, 1.0 , and $3.0 \mathrm{wt}$ pct). The density, viscosity, and surface tension were obtained using the free flow method. Differential scanning calorimetry (DSC) measurements were taken to determine the melting point, then the specified linear expansion was determined by dilatometry and resistivity measurements, using the four-point probe method. The characteristic microstructures of the obtained cast alloys were also observed by SEM and analysis of the occurring phase using X-ray diffraction (XRD) analysis, and a mechanical test was carried out to show the positive effect of $\mathrm{Ga}$ addition to eutectic SnZn alloys.

\section{EXPERIMENTAL}

High purity metals Sn, Zn, and Ga (99.999 pct), were used for the preparation of the alloys. Samples were melted in a furnace placed in a glove box with high purity argon, to provide the best possible protective atmosphere during the experiment. The level of $\mathrm{O}_{2}$ and $\mathrm{H}_{2} \mathrm{O}$ was below $1 \mathrm{ppm}$ as measured by solid-state analyzers for oxygen and moisture, and the $\mathrm{N}_{2}$ content was lowered (although it was not monitored), owing to $\mathrm{Ar}$ gas circulating through the high temperature purification system filled with Ti shavings heated to $1123 \mathrm{~K}$ $\left(850^{\circ} \mathrm{C}\right)$. In order to prepare samples for electrical resistivity measurements, the liquid alloys were sucked into quartz capillaries of $2 \mathrm{~mm}$ uniform inner diameter, in which they solidified rapidly. ${ }^{[6]}$ The equipment and experimental procedure for DSC, thermo-mechanical analysis (TMA), electrical resistivity, and mechanical tests were described. ${ }^{[6]}$ To measure the physicochemical properties of SnZnGa alloys, the discharge crucible 
method (DC) ${ }^{[7]}$ was used. The free outflow of molten metal occurred through an orifice of specified diameter in the bottom of a crucible, and from a measurement of the mass of molten metal flowing out of the crucible as a function of time, the surface tension, density, and viscosity could be calculated simultaneously, from one experiment. Calibration involved the use of a crucible with a hole, and the parameters specifying the experiment were obtained for pure metals $\mathrm{Sb}, \mathrm{Sn}$, and $\mathrm{Zn} .^{\left[{ }^{8]}\right.}$ The liquid metal temperature was controlled with a thermocouple placed inside the crucible and connected to a temperature controller. The equipment for the DC method was constructed and placed in a glove box with high purity argon, to provide the best possible protective atmosphere during the experiment. The microstructure characteristics and elemental analysis were analyzed using scanning electron microscopy (SEM) coupled with energy dispersive spectrometry (EDS), and XRD to improve the occurring phases. Mechanical tests were conducted on an INSTRON 6025 testing machine modernised by Zwick/Roell. The conditions of testing were in accordance with EN ISO 6892-1:2009, with a strain rate of $0.00025(1 / \mathrm{s})$ at room temperature. The tensile and compressive tests were performed for each of the SnZn alloys with Ga additions, and three successful measurements were taken. The samples for tensile tests were cast to graphite molds $(\varnothing 8 \times 100 \mathrm{~mm})$ with the base measuring $5 \mathrm{~mm}$ diameter and $40 \mathrm{~mm}$ length.

\section{RESULTS AND DISCUSSIONS}

The DSC curves of SnZn alloys with Ga addition are presented in Figure 1. With increasing Ga addition to eutectic SnZn, the melting temperature reduced and the same results were obtained. ${ }^{[2,4]}$ Song et al. ${ }^{[4]}$ recorded a melting point of $468 \mathrm{~K}\left(195^{\circ} \mathrm{C}\right)$ for $1.8 \mathrm{Ga}$, compared to $472 \mathrm{~K}\left(199{ }^{\circ} \mathrm{C}\right.$ ) for 2 (wt pct) $\mathrm{Ga}$ obtained by Reference 2. But Zhang et al., ${ }^{[2]}$ for alloys with higher Ga content, recorded a greater decrease of the melting point [468 K, $461 \mathrm{~K}, 447 \mathrm{~K}$, and $428 \mathrm{~K}\left(195{ }^{\circ} \mathrm{C}, 188^{\circ} \mathrm{C}\right.$, $174{ }^{\circ} \mathrm{C}$, and $155^{\circ} \mathrm{C}$ ) for $3,4,6$, and 8 (wt pet) Ga, respectively]. According to the phase diagram of Ga-Sn-Zn, ${ }^{[2]}$ which is built from the binary eutectic components, of E1 Sn8.8Zn [471.5 K $\left.\left(198.5^{\circ} \mathrm{C}\right)\right]$, E2 Ga15Zn (292.0 K $\left(19^{\circ} \mathrm{C}\right)$ ), and E3 Ga4Sn (298 K $\left(25^{\circ} \mathrm{C}\right)$ ). In this ternary system, the eutectic points formed a triangle that can be described as a pseudo-binary eutectic Ga-Sn8.8Zn section, and the calculated eutectic point of the ternary system is $283 \mathrm{~K}\left(10^{\circ} \mathrm{C}\right) .^{[2]}$ For the samples with 3.0 (wt pct) addition of $\mathrm{Ga}$, the regions of high $\mathrm{Ga}$ concentration with $\mathrm{Sn}$ or $\mathrm{Zn}$ start to dissolve from $323 \mathrm{~K}\left(50{ }^{\circ} \mathrm{C}\right)$, and this reaction reaches its maximum at $392 \mathrm{~K}\left(119{ }^{\circ} \mathrm{C}\right)$. The same behavior was observed in thermal expansion coefficient (CTE) and electrical resistivity measurements.

Physical data on density, viscosity, and surface tension were obtained from the DC method. ${ }^{[7]}$ The method consists of allowing the free flow of the liquid alloy through a hole in the bottom of the crucible, to a second crucible which is on a set of scales. The changes of mass $v s$ time data obtained from the experiment, and use of the numerical method, allow Eq. [1] to be solved and give all three properties. ${ }^{[7,8]}$

$$
h=\frac{1}{2 g}\left(\frac{Q}{\left(a_{4}\left(\frac{2 \rho Q}{\pi r_{0} \eta}\right)^{3}+a_{3}\left(\frac{2 \rho Q}{\pi r_{0} \eta}\right)^{2}+a_{2}\left(\frac{2 \rho Q}{\pi r_{0} \eta}\right)+a_{1}\right) \pi r_{0}^{2}}\right)+\frac{\sigma}{\rho g r_{0}}
$$

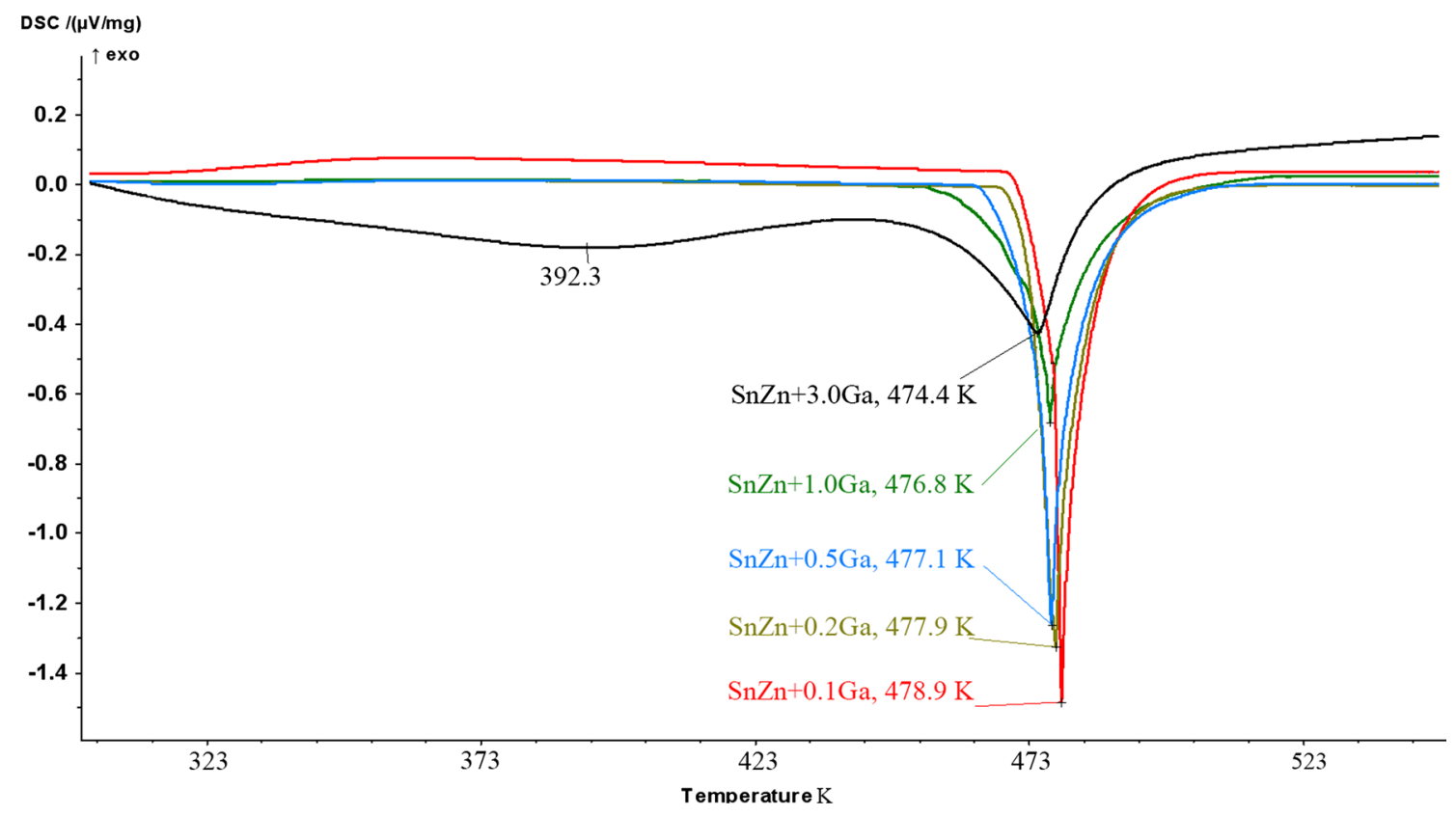

Fig. 1-DSC measurements of SnZn alloys with Ga (Color figure online). 
where $\rho$ density of liquid $\left(\mathrm{kg} / \mathrm{m}^{3}\right), g$ gravitational acceleration $\left(\mathrm{m} / \mathrm{s}^{2}\right), r_{0}$ orifice radius in the bottom of crucible $(\mathrm{m}), \sigma$ surface tension $(\mathrm{mN} / \mathrm{m}), Q$ free flow $\left(\mathrm{m}^{3} /\right.$ $\mathrm{s}), \eta$ viscosity ( $\mathrm{mPa} \mathrm{s}$ ), $a_{1}, a_{2}$, and $a_{3}$ are constants in the polynomial describing $C_{\mathrm{d}} v s \mathrm{Re}, C_{\mathrm{d}}$ discharge coefficient determined for a given crucible based on the free flow of liquids with known density, Re Reynolds number.

Density, viscosity, and surface tension are presented in Figure 2. The properties of pure $\mathrm{Ga}$ at $623 \mathrm{~K}\left(350{ }^{\circ} \mathrm{C}\right)$ (density $5.921\left(\mathrm{~g} / \mathrm{cm}^{3}\right)$, surface tension $696.0(\mathrm{mN} / \mathrm{m})$, and viscosity $0.942(\mathrm{mPa} \mathrm{s})$ ) were taken from Reference 9. Compared to eutectic SnZn $6.900\left(\mathrm{~g} / \mathrm{cm}^{3}\right), 546.1(\mathrm{mN} / \mathrm{m})$, $1.652(\mathrm{mPa} \mathrm{s}),{ }^{[10]}$ the addition of $\mathrm{Ga}$ to $\mathrm{SnZn}$, caused a reduction of surface tension, density, and viscosity. As expected, the density and viscosity of $\mathrm{SnZnGa}$ alloys are lower than those of eutectic SnZn, ${ }^{[10]}$ whereas a decrease of surface tension [about 2 pct in the case of alloy containing of 3 (wt pct) of Ga] is not uncommon, because of the similar effect of a small addition of high surface tension component, as observed earlier in the case of Ga-Sn. ${ }^{[1]} \mathrm{In}$ the Ga-Sn and Ga-Zn system, ${ }^{[11]}$ negative deviations from the ideal solutions were observed. In the SnZn with $\mathrm{Ga}$ doped to 3.0 (wt pct), surface tension slightly reduced with $\mathrm{Ga}$ addition, as shown in Figure 2(b). Reduction of density (Figure 2(a)) and viscosity (Figure 2(c)) for SnZn with $\mathrm{Ga}$, are caused by dissolved $\mathrm{Ga}$ in eutectic $\mathrm{SnZn}$, which shows on the microstructure of the cast alloys (Figure 3), and is also indicated in phase diagrams of Ga-Sn, Ga-Zn ${ }^{[14]}$ and Ga-Sn-Zn. ${ }^{[2]}$ In the case of the $\mathrm{SnZn}+\mathrm{Na}$ system, viscosity increased with the addition of Na, caused by the creation of IMPs precipitates. The obtained density, surface tension, and viscosity for $\mathrm{SnZn}+\mathrm{Ga}$ were lower compared to the literature data for eutectic PbSn $8.127\left(\mathrm{~g} \mathrm{~cm}^{-3}\right), 495\left(\mathrm{mN} \mathrm{m}^{-1}\right),{ }^{[12]}$ and $1.864 \mathrm{mPa} \mathrm{s}^{[13]}$ respectively, at a temperature of $623 \mathrm{~K}$ $\left(350{ }^{\circ} \mathrm{C}\right)$. Temperature dependencies of density, surface tension, and viscosity are presented in Table I. The values obtained were described by the linear and Arrhenius equations, and the parameters of the equation presented in the table, along with the density, surface tension, and viscosity values, are calculated for a temperature of $623 \mathrm{~K}$ $\left(350{ }^{\circ} \mathrm{C}\right)$.

The microstructure of the casting alloys are presented in Figure 3 for (a) 0.1, (b) 0.2, (c) 0.5, (d) 1.0, and (e) 3.0 (wt pct) content Ga in SnZnGa alloys. For 3.0 (wt pct) $\mathrm{Ga}$, the secondary electron micrographs and EDS elemental maps for $\mathrm{Ga}, \mathrm{Sn}$, and $\mathrm{Zn}$ were done. On the EDS maps, the dispersion of $\mathrm{Ga}$ in the entire volume of the sample is shown. In Table II, the EDS analysis obtained for $\mathrm{SnZn}$ with 1.0 (wt pct) Ga, presenting Ga occurrence in the $\mathrm{Sn}$ and $\mathrm{Zn}$ region, is shown. The XRD analyses are shown in Figure 4. EDS analysis revealed the dissolution of $\mathrm{Ga}$ in $\mathrm{Sn}$ and $\mathrm{Zn}$, which is in agreement with the phase diagram of $\mathrm{Ga}-\mathrm{Sn}$ and Ga-Zn. ${ }^{[14]}$ Comparing the obtained microstructure with the literature, such as Song et al. ${ }^{[4]}$ and Chen et al., ${ }^{[15]}$ the Ga content to 3.0 pet does not change the structure of the eutectic SnZn.

Electrical resistivity is presented in Figure 5, for (a) temperature dependences of SnZn alloys doped with Ga,

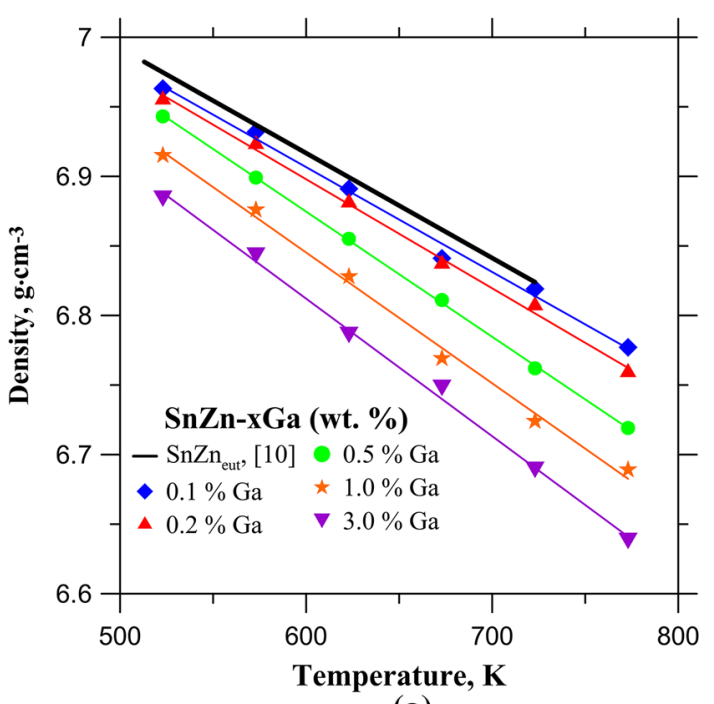

(a)

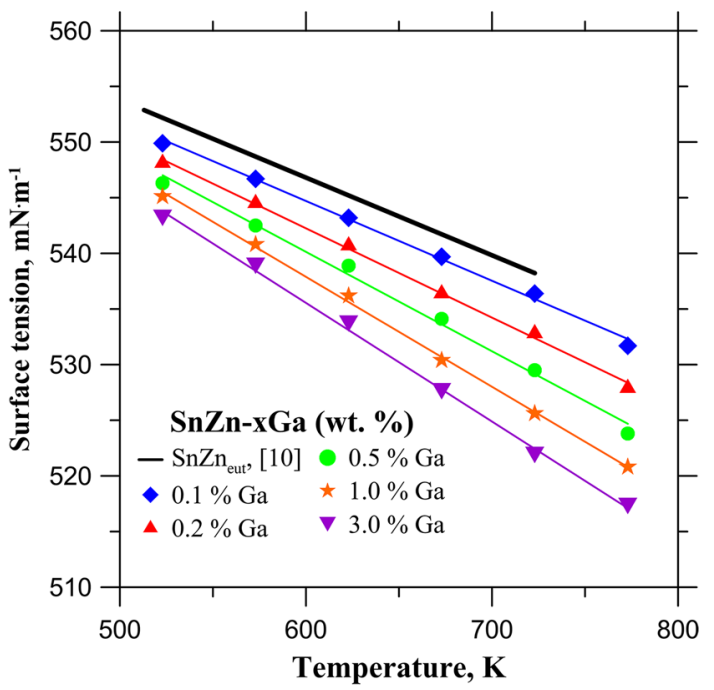

(b)

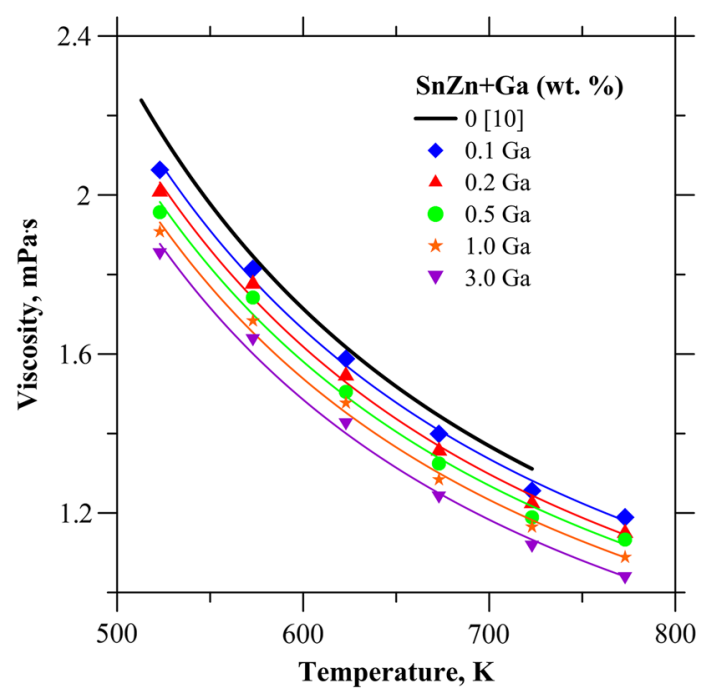

(c)

Fig. 2-Physicochemical properties of SnZn with Ga, (a) density, (b) surface tension, and $(c)$ viscosity (Color figure online). 


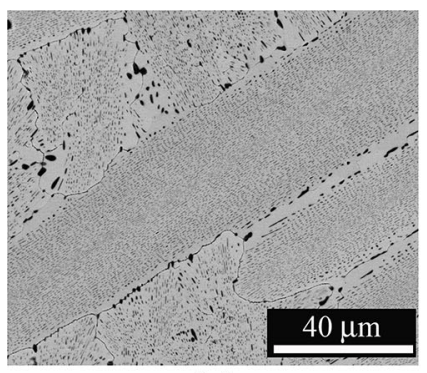

(a)

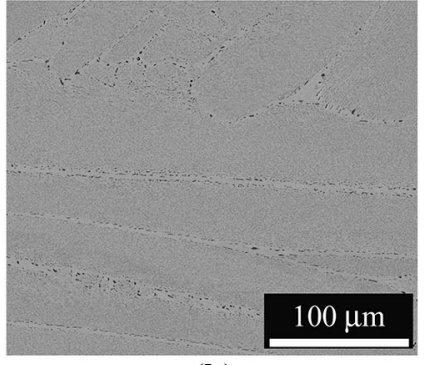

(b)

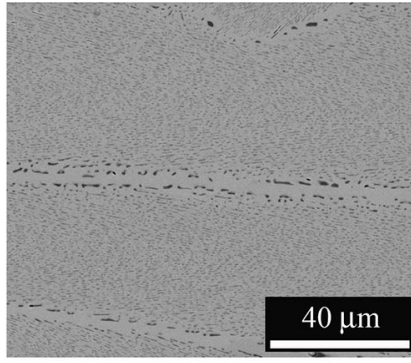

(c)

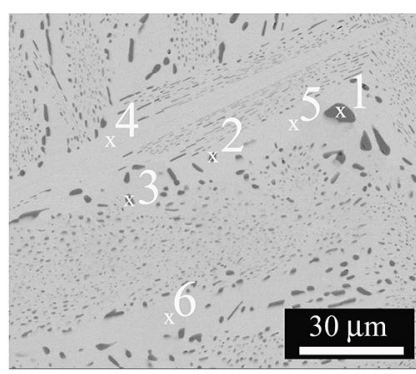

(d)
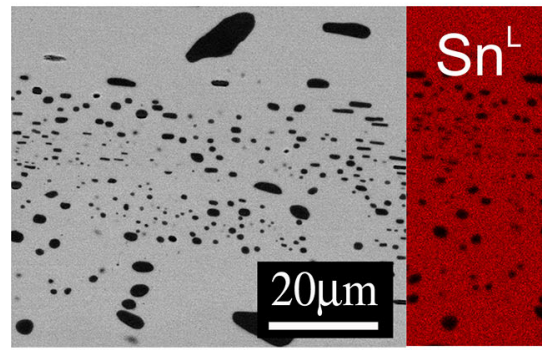

s.

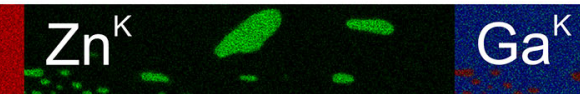

\section{K}

Fig. 3-Microstructure of cast alloys SnZn with Ga, $(a) 0.1,(b) 0.2,(c) 0.5$, and $(d) 1.0$ with marked points of EDS analysis and (e) 3.0 (wt pct) and EDS maps.

Table I. Linear and Arrhenius Dependence for SnZn with Ga Addition for Density $(\rho)$, Surface Tension $(\sigma)$, and Viscosity $(\eta)$, with Errors and Parameters, Determined for a Temperature of $623 \mathrm{~K}\left(350{ }^{\circ} \mathrm{C}\right)$

\begin{tabular}{|c|c|c|c|c|c|c|}
\hline Alloys (Weight Percent) & $A$ & $\delta A$ & $B$ & $\delta B$ & $\rho, \mathrm{g} \mathrm{cm}^{-3} 623 \mathrm{~K}\left(350{ }^{\circ} \mathrm{C}\right)$ & $\delta \rho$ \\
\hline $\mathrm{SnZn}+0.1 \mathrm{Ga}$ & 7.36 & 0.02 & 0.00075 & 0.00003 & 6.626 & 0.265 \\
\hline $\mathrm{SnZn}+0.2 \mathrm{Ga}$ & 7.37 & 0.01 & 0.00078 & 0.00002 & 6.606 & 0.275 \\
\hline $\mathrm{SnZn}+0.5 \mathrm{Ga}$ & 7.41 & 0.01 & 0.00090 & 0.00001 & 6.539 & 0.316 \\
\hline $\mathrm{SnZn}+1.0 \mathrm{Ga}$ & 7.41 & 0.02 & 0.00094 & 0.00003 & 6.495 & 0.333 \\
\hline $\mathrm{SnZn}+3.0 \mathrm{Ga}$ & 7.41 & 0.02 & 0.00099 & 0.00003 & 6.443 & 0.343 \\
\hline Alloys (Weight Percent) & $A$ & $\delta A$ & $B$ & $\delta B$ & $\sigma, \mathrm{mN} \mathrm{m}^{-1} 623 \mathrm{~K}\left(350^{\circ} \mathrm{C}\right)$ & $\delta \sigma$ \\
\hline $\mathrm{SnZn}+0.1 \mathrm{Ga}$ & 587.7 & 1.4 & -0.072 & 0.002 & 517.98 & 25.22 \\
\hline $\mathrm{SnZn}+0.2 \mathrm{Ga}$ & 590.4 & 1.2 & -0.080 & 0.002 & 512.33 & 28.37 \\
\hline $\mathrm{SnZn}+0.5 \mathrm{Ga}$ & 593.7 & 2.4 & -0.089 & 0.004 & 506.82 & 32.08 \\
\hline $\mathrm{SnZn}+1.0 \mathrm{Ga}$ & 597.2 & 1.3 & -0.099 & 0.002 & 501.04 & 35.16 \\
\hline $\mathrm{SnZn}+3.0 \mathrm{Ga}$ & 599.5 & 1.7 & -0.107 & 0.003 & 495.78 & 37.92 \\
\hline Alloys (Weight Percent) & $A$ & $\delta A$ & $E$ & $\delta E$ & $\eta, \mathrm{mPa}$ s $623 \mathrm{~K}\left(350{ }^{\circ} \mathrm{C}\right)$ & $\delta \eta$ \\
\hline $\mathrm{SnZn}+0.1 \mathrm{Ga}$ & 0.360 & 0.006 & 7633.1 & 22.8 & 1.571 & 0.017 \\
\hline $\mathrm{SnZn}+0.2 \mathrm{Ga}$ & 0.349 & 0.008 & 7649.1 & 31.5 & 1.527 & 0.018 \\
\hline $\mathrm{SnZn}+0.5 \mathrm{Ga}$ & 0.340 & 0.005 & 7671.1 & 37.8 & 1.494 & 0.011 \\
\hline $\mathrm{SnZn}+1.0 \mathrm{Ga}$ & 0.328 & 0.006 & 7713.2 & 25.8 & 1.453 & 0.024 \\
\hline $\mathrm{SnZn}+3.0 \mathrm{Ga}$ & 0.302 & 0.005 & 7938.8 & 30.2 & 1.400 & 0.023 \\
\hline
\end{tabular}

Table II. EDS Analysis of SnZn1.0Ga Marked in Fig. 3(d), at Weight Percent

\begin{tabular}{lrrrrr}
\hline Element/Marked Point & 1 & 2 & 3 & \multicolumn{1}{c}{4} & \multicolumn{1}{c}{5} \\
\hline $\mathrm{Sn}^{\mathrm{L}}$ & 8.85 & 9.58 & 14.45 & 97.98 & 97.91 \\
$\mathrm{Zn}^{\mathrm{K}}$ & 89.90 & 89.25 & 84.68 & 0.62 & 0.63 \\
$\mathrm{Ga}^{\mathrm{K}}$ & 1.25 & 1.17 & 0.87 & 1.40 & 0.82 \\
\hline
\end{tabular}




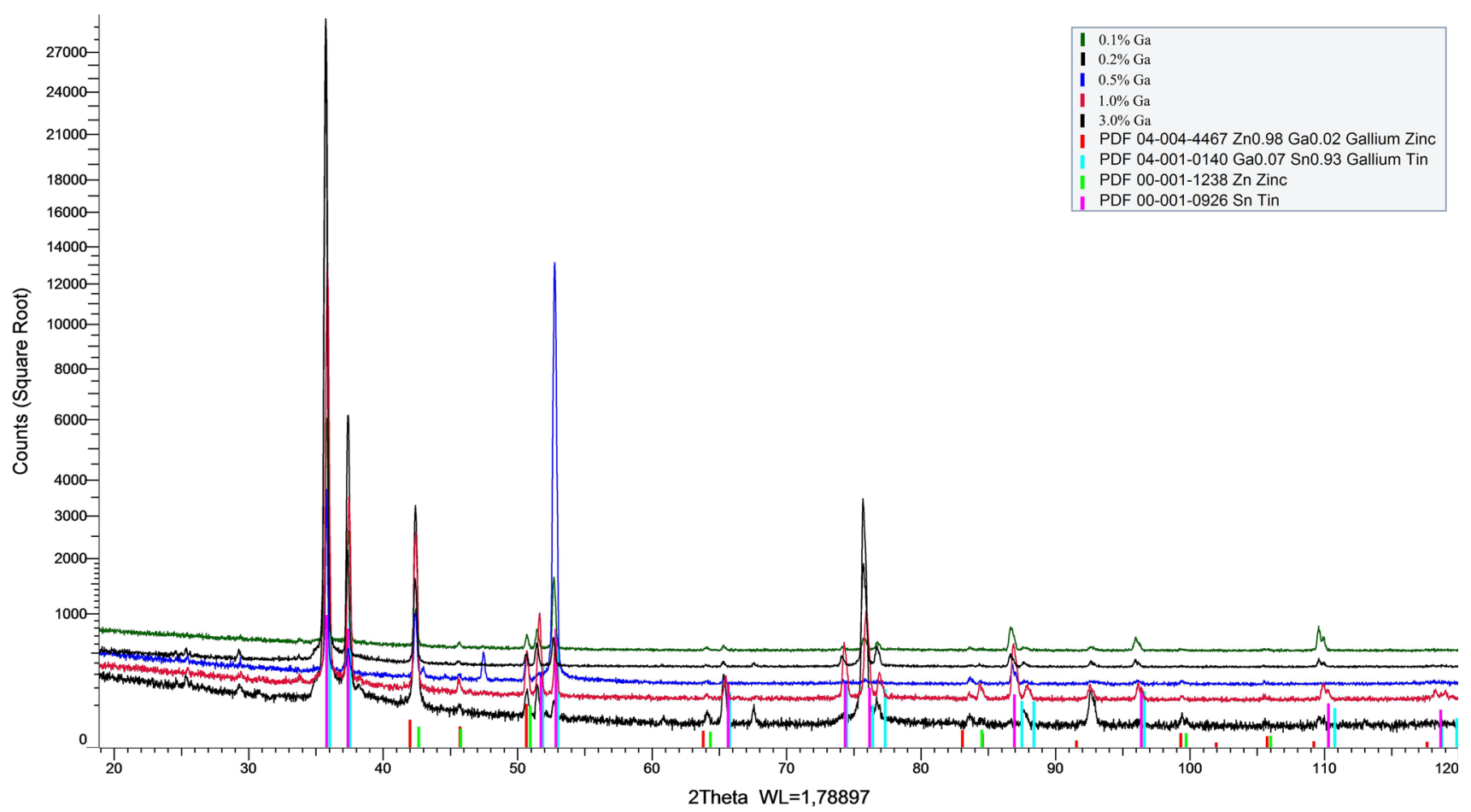

Fig. 4-XRD analyses of SnZn alloys with Ga (Color figure online).

and (b) the influence of the addition of Ga to SnZn alloys at $373 \mathrm{~K}\left(100{ }^{\circ} \mathrm{C}\right)$ for electrical resistivity. The influence of $\mathrm{Ga}$ on $\mathrm{SnZn}$ alloys means that a small addition of $\mathrm{Ga}$ reduces electrical resistivity [up to 0.5 (wt pct) Ga], and after that point increases it. The reducing of electrical resistivity is related to the solubility limit of $\mathrm{Ga}$ in $\mathrm{Sn}$ and $\mathrm{Zn}$ according to phase diagrams of Ga-Sn and Ga-Zn ${ }^{[14]}$ Beyond this limit, the electrical resistivity increases with increasing Ga content in alloys. In the case of SnZn with $\mathrm{In}^{[16]}$ the electrical resistivity increases with the addition of In to alloys. All received data for $\mathrm{SnZn}+\mathrm{Ga}$ alloys show that electrical resistivity is higher compared to eutectic $\mathrm{SnZn},{ }^{[16]}$ but lower compared to eutectic $\mathrm{Sn} 37 \mathrm{~Pb} \cdot{ }^{[16]}$ For the addition of 3.0 (wt pct) Ga, three temperature ranges in the slope of the electrical resistivity line were observed. Changes of the same character were observed for linear expansion for $\mathrm{SnZn}+3 \mathrm{Ga}$ (wt pct). The electrical resistivity of eutectic $\mathrm{Sn} 37 \mathrm{~Pb}$ (wt pct) alloy is $14.50(\mu \Omega \mathrm{cm})$, which is very high compared to eutectic SnZn alloy $11.70(\mu \Omega \mathrm{cm})$ and $\mathrm{SnZn}$ with Ga from 12.09, 12.03, $12.02,12.86$, and $14.41(\mu \Omega \mathrm{cm})$ at $298 \mathrm{~K}\left(25^{\circ} \mathrm{C}\right)$. This lower value leads to reduced loss of energy and increased efficiency, thus expanding the possibility of the application of SnZn with Ga in industry.
Linear expansion for $\mathrm{SnZn}$ alloys with $\mathrm{Ga}$ is presented in Figure 6, and the CTE in Table III. The different trends obtained for $\mathrm{SnZn}+\mathrm{Ga}$ is compared to $\mathrm{SnZn}+\mathrm{In}^{[16]}$ In the literature, linear expansion data increase with the addition of In. For CTE, this expansion increases up to 1.0 (wt pct) $\mathrm{Ga}$, and reduces for 3.0 (wt pct) Ga. The solubility limit of Ga in $\mathrm{Sn}$ and $\mathrm{Zn}$ has an influence on linear expansion, as shown on the phase diagram..$^{[2]}$ The 3 (wt pct) of Ga is very close to the chemical content in $\mathrm{SnZnGa}$, when observed as a liquid at room temperature. The linear thermal expansion vs temperature for $\mathrm{SnZn}+3.0 \mathrm{Ga}$ (wt pct) alloy show changes to the slope, which has an impact on the value of CTE. The same changes were observed in electrical resistivity and DSC measurement, indicating that surplus $\mathrm{Ga}$ leads to changes of these properties.

The effect of $\mathrm{Ga}$ addition to eutectic $\mathrm{SnZn}$ on mechanical properties can be seen from the strain-stress curves shown in Figure 7. The ultimate tensile strength and elongation values are summarised in Table IV. The $\mathrm{R}_{\mathrm{p} 0.2}$ (plastic strain of $0.2 \mathrm{pct}$ ), $R_{\mathrm{m}}$ (tensile strength), and $A_{5.65}$ (percentage elongation after fracture) were obtained from tensile testing. The Ga additions caused increasing tensile strength, but at the same time elongation was reduced. The tensile strength of the Sn-37Pb, 


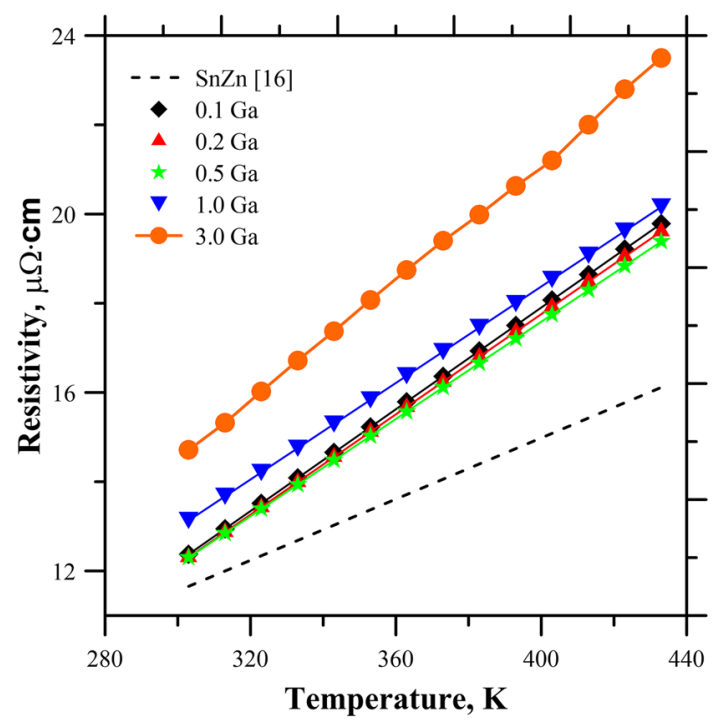

(a)

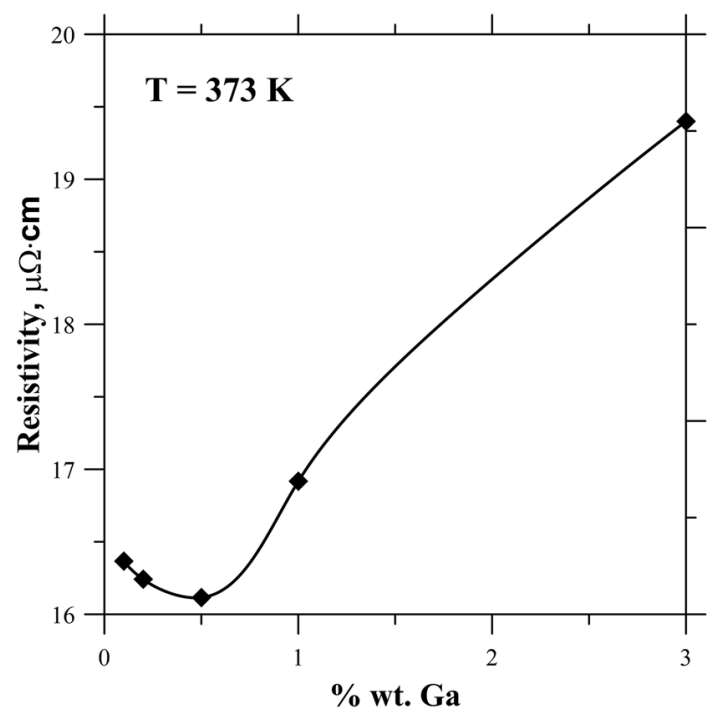

(b)

Fig. 5-Electrical resistivity for SnZn with $\mathrm{Ga}$, (a) temperature dependence, and $(b)$ with changes of $\mathrm{Ga}$ content at a temperature of $373 \mathrm{~K}\left(100{ }^{\circ} \mathrm{C}\right)$ (Color figure online).

Sn-9Zn, Sn-9Zn-0.5Ag, Sn-9Zn-0.5Al, and Sn-9Zn-0.5Ga (wt pct) were 55, 78, 62, 73, and $78 \mathrm{MPa}$, respectively, according to data obtained by Chen et al. ${ }^{[15]}$ Comparing the literature data ${ }^{[15]}$ with the results obtained from the experiment, the tensile strength for 1.0 and 3.0 (wt pct) Ga are higher. All of the SnZnGa alloys showed higher values of tensile strength than $\mathrm{Sn}-37 \mathrm{~Pb} .^{[15]}$ The addition of $\mathrm{Ga}$ to $\mathrm{SnZn}$ reduced the elongation very quickly. For 0.5 (wt pct) $\mathrm{Ga}$ this was 16.8 pct, while the literature data on elongation for $\mathrm{Sn}-37 \mathrm{~Pb}, \mathrm{Sn}-9 \mathrm{Zn}$, Sn-9Zn-0.5Ag, Sn-9Zn-0.5Al, and Sn-9Zn-0.5Ga were $38,41,37,38$, and 41 pct, respectively. ${ }^{[15]}$ Although the obtained data and ${ }^{[15]}$ value of tensile strength for $\mathrm{SnZn}$ with $0.5 \mathrm{Ga}$ are almost the same, the elongation value is a factor of the two smaller. Song et al. ${ }^{[4]}$ obtained elongation of more than 50 pct for SnZn alloys with $\mathrm{Ga}$ addition to 1.0 (wt pct), and recorded reduced elongation to $\sim 30 \mathrm{pct}$ for $1.8 \mathrm{Ga}$, but the tensile strength was similar to that presented in this work. The various results obtained for elongation could be due to different preparations of alloys, even for similar morphologies, which were obtained by References 4 and 15. Osorio et al. ${ }^{[17]}$ show the influence of preparation of samples for obtained stress and elongation for eutectic SnAg, $\mathrm{SnBi}, \mathrm{SnZn}, \mathrm{SnPb}$ alloys. The most sensitive was eutectic $\mathrm{SnZn}$, for which the obtained stress value ranged from $\sim 41$ to $\sim 59(\mathrm{MPa})$, and strain from 50 to 26 pct. This study and Reference 4 confirm the occurring trend of increasing tensile strength with the addition of $\mathrm{Ga}$ to $\mathrm{SnZn}$. From the viewpoint of $\mathrm{SnZnGa}$ alloys as a replacement for lead solders, increasing the stress will raise the strength of soldered connections.

\section{SUMMARY}

The addition of Ga to a eutectic SnZn alloy generally reduced density, surface tension, viscosity, and melting point, and increased the coefficient of thermal expansion and electrical resistivity. The obtained density, surface tension, and viscosity for $\mathrm{SnZn}+\mathrm{Ga}$ were lower compared to the literature data for eutectic PbSn. ${ }^{[12,13]}$ Increasing addition of Ga to eutectic SnZn alloys caused increasing tensile strength but reduced elongation values. The DSC measurement for the alloy $\mathrm{SnZn}+3.0 \mathrm{Ga}$ (wt pct) shows dissolution, which starts around $323 \mathrm{~K}$ $\left(50{ }^{\circ} \mathrm{C}\right)$, which is also apparent in regard to thermal expansion and electrical resistivity, and which is in line with the phase diagram of Ga-Sn-Zn. ${ }^{[2]}$ The microstructures of $\mathrm{SnZn}+\mathrm{Ga}$ are similar to eutectic $\mathrm{SnZn}$ and the same as obtained in References 4 and 15. 


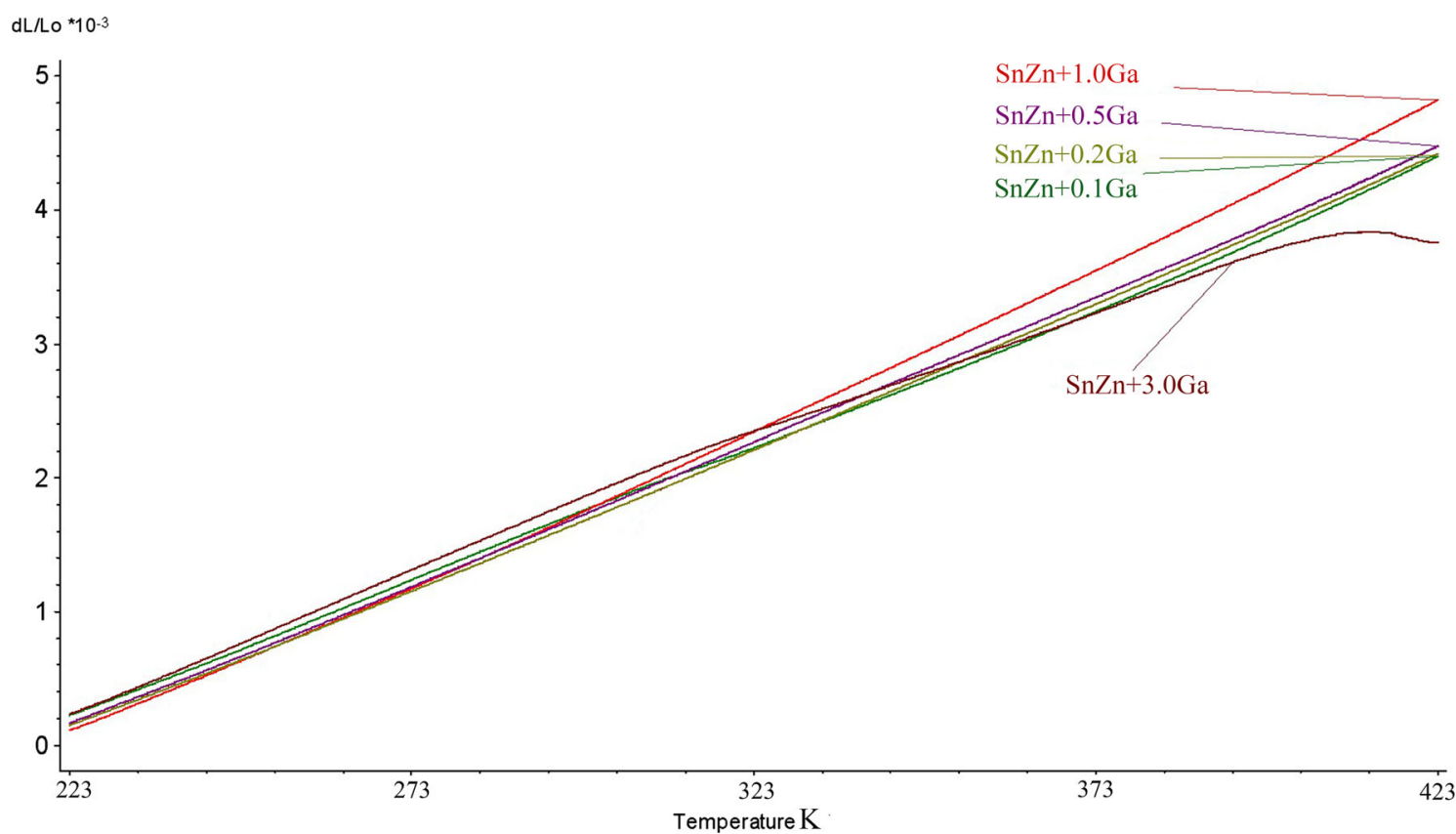

Fig. 6-The linear expansion for SnZn alloys with Ga (Color figure online).

Table III. CTE Parameters of SnZn with Ga Alloys

\begin{tabular}{lcc}
\hline Composition & Temperature Range $\left[\mathrm{K}\left({ }^{\circ} \mathrm{C}\right)\right]$ & $\mathrm{CTE}, 10^{-6} \mathrm{~K}^{-1}$ \\
\hline $\mathrm{SnZn}_{\mathrm{E}}[16]$ & $223 \mathrm{~K}$ to $473 \mathrm{~K}\left(-50^{\circ} \mathrm{C}\right.$ to $\left.200{ }^{\circ} \mathrm{C}\right)$ & 20.88 \\
$\mathrm{SnZn}+0.1 \mathrm{Ga}$ & $223 \mathrm{~K}$ to $473 \mathrm{~K}\left(-50^{\circ} \mathrm{C}\right.$ to $\left.200^{\circ} \mathrm{C}\right)$ & 20.88 \\
$\mathrm{SnZn}+0.2 \mathrm{Ga}$ & $223 \mathrm{~K}$ to $473 \mathrm{~K}\left(-50^{\circ} \mathrm{C}\right.$ to $\left.200^{\circ} \mathrm{C}\right)$ & 20.90 \\
$\mathrm{SnZn}+0.5 \mathrm{Ga}$ & $223 \mathrm{~K}$ to $473 \mathrm{~K}\left(-50{ }^{\circ} \mathrm{C}\right.$ to $\left.200^{\circ} \mathrm{C}\right)$ & 21.55 \\
$\mathrm{SnZn}+1.0 \mathrm{Ga}$ & $223 \mathrm{~K}$ to $473 \mathrm{~K}\left(-50^{\circ} \mathrm{C}\right.$ to $\left.200{ }^{\circ} \mathrm{C}\right)$ & 23.55 \\
$\mathrm{SnZn}+3.0 \mathrm{Ga}$ & $223 \mathrm{~K}$ to $323 \mathrm{~K}\left(-50^{\circ} \mathrm{C}\right.$ to $\left.200^{\circ} \mathrm{C}\right)$ & 21.43 \\
\hline
\end{tabular}

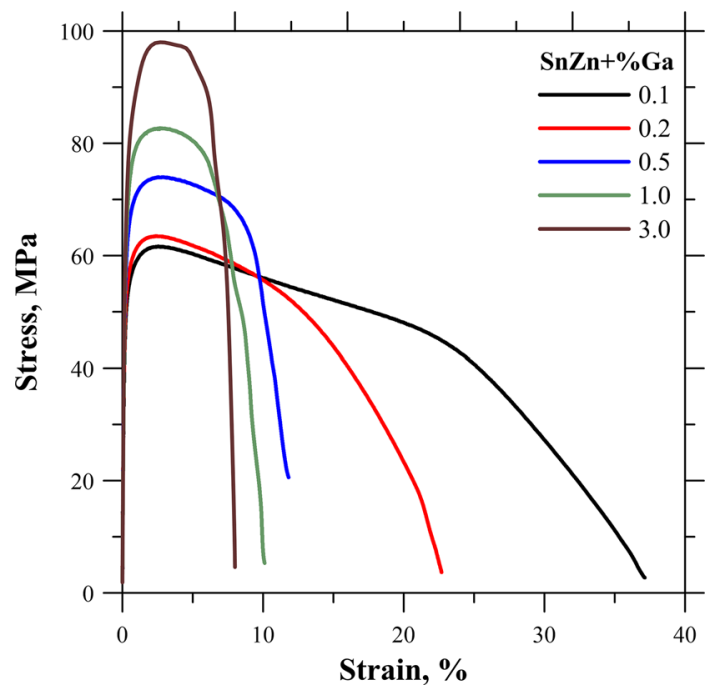

Fig. 7-Mechanical properties of SnZn with Ga addition for the strain-stress curves (Color figure online).
Table IV. The Tensile Strength and Elongation Values of SnZn with (Weight Percent) Ga

\begin{tabular}{lccc}
\hline Alloys & $R_{\mathrm{p} 0.2}(\mathrm{MPa})$ & $R_{\mathrm{m}}(\mathrm{MPa})$ & $A_{5,65}(\mathrm{Pct})$ \\
\hline SnZn0.1Ga & 51.9 & 60.8 & 37.5 \\
SnZn0.2Ga & 55.6 & 65.4 & 27.8 \\
SnZn0.5Ga & 56.9 & 73.9 & 16.8 \\
SnZn1.0Ga & 68.4 & 82.4 & 11.9 \\
SnZn3.0Ga & 74.7 & 98.5 & 9.8 \\
\hline
\end{tabular}

\section{ACKNOWLEDGMENT}

This work was financed by the National Science Centre Poland grant 2013/09/D/ST8/03991 "Physicochemical properties of $\mathrm{SnZn}+\mathrm{X}(\mathrm{X}=\mathrm{Ga}, \mathrm{Na})$ alloys" in the year 2014 to 2017. 


\section{OPEN ACCESS}

This article is distributed under the terms of the Creative Commons Attribution 4.0 International License (http://creativecommons.org/licenses/by/4.0/), which permits unrestricted use, distribution, and reproduction in any medium, provided you give appropriate credit to the original author(s) and the source, provide a link to the Creative Commons license, and indicate if changes were made.

\section{REFERENCES}

1. L. Zhang and K.N. Tu: Mater. Sci. Eng. R, 2014, vol. 82, pp. 1-32.

2. Y. Zhang, T. Liang, and M.A. Jusheng: J. Non-Cryst. Solids, 2004, vol. 336, pp. 153-56

3. W.-X. Chen, S.-B. Xue, and H. Wang: Mater. Des., 2010, vol. 31, pp. 2196-2200.

4. J.M. Song, N.S. Liu, and K.-L. Lin: Mater. Trans., 2004, vol. 45, pp. $776-82$.
5. H. Ye, S. Xue, J. Luo, and Y. Li: Mater. Des., 2013, vol. 46, pp. 816-23.

6. T. Gancarz and J. Pstrus: Arch. Metall. Mater., 2015, vol. 60, pp. 1603-07.

7. T. Gancarz, W. Gasior, and H. Henein: Int. J. Thermophys., 2014, vol. 35 , pp. $1725-48$.

8. T. Gancarz, W. Gasior, and H. Henein: Int. J. Thermophys., 2013, vol. 34, pp. 250-66.

9. W.R. Gale and T.C. Totemaier, eds.: Smithells Metals Reference Book, Elsevier, Butterworth-Heinemann Ltd., Oxford, 2004.

10. T. Gancarz, J. Pstruś, W. Gạsior, and H. Henein: J. Electron. Mater., 2013, vol. 42, pp. 288-93.

11. R. Novakovic and D. Zivkovic: J. Mater. Sci., 2005, vol. 40, pp. 2251-57.

12. W. Gasior, Z. Moser, and J. Pstrus: J. Phase Equilib. Differ., 2001, vol. 22, pp. 20-25.

13. W. Gasior, Z. Moser, J. Pstrus, and M. Kucharski: Arch. Metall. Mater., 2001, vol. 46, pp. 23-32.

14. SGTE-SGTE alloy phase diagrams, http://www.crct.polymtl. ca/FACT/documentation/SGTE/SGTE_Figs.htm.

15. K.-I. Chen, S.-C. Cheng, S. Wu, and K.-L. Lin: J. Alloys. Compd., 2006, vol. 416, pp. 98-105.

16. T. Gancarz, P. Fima, and J. Pstruś: J. Mater. Eng. Perform., 2014, vol. 5, pp. 1524-29.

17. W. Osorio, L. Peixoto, L. Garcia, N. Mangelinck-Noël, and A. Garcia: J. Alloy Compd., 2013, vol. 572, pp. 97-106. 